\title{
Customer Loyalty of Kanggo Riko Coffee Shop Sidoarjo
}

Noerchoidah $^{1 *}$, Christina Menuk Handayani2 ${ }^{2}$, Wahyu Priyanto ${ }^{3}$

1,2,3Faculty of Economics and Business, PGRI Adi Buana University Surabaya e-mail: noerchoidah@unipasby.ac.id ${ }^{1}$

*Corresponding Author: E-mail: noerchoidah@unipasby.ac.id

\begin{tabular}{lll}
\hline ARTICLE INFO & ABSTRACT \\
\cline { 1 - 1 } $\begin{array}{l}\text { Received November 2021 } \\
\text { Accepted November 2021 } \\
\text { Published December 2021 }\end{array}$ & $\begin{array}{l}\text { This study examines the effect of price, product diversity, } \\
\text { facilities, and location on customer loyalty at Kedai Kopi Kanggo } \\
\text { Riko Sidoarjo. A total of } 120 \text { customers were used as samples in } \\
\text { this study with incidental sampling technique. Data were } \\
\text { Keywords: Facilities, } \\
\begin{array}{l}\text { Location and Loyalty, Price, } \\
\text { Product Diversity. }\end{array}\end{array}$ \\
$\begin{array}{l}\text { significant influence between price and customer loyalty, product } \\
\text { diversity affects loyalty, facilities affect customer loyalty, location } \\
\text { affects customer loyalty. Simultaneously price, product diversity, } \\
\text { facilities, and location affect customer loyalty. These results } \\
\text { provide evidence that Kedai Kopi Kanggo Riko Sidoarjo can } \\
\text { increase customer loyalty by emphasizing price factors, product } \\
\text { diversity, facilities, and location. }\end{array}$ \\
\hline
\end{tabular}

\section{Introduction}

The current business developments have caused very tight competition between various companies. Events force market participants to act quickly in determining and implementing competitive strategies to survive in the market. Today every organization must be obligated to be customer-oriented because customers are one of the ways for companies to win the competition in the market [9]. Competition between companies that produce similar products or services is increasingly competitive. This condition requires companies to create opportunities and be able to meet customer needs in order to be able to maintain business sustainability [10].

Coffee shops are something that is not foreign to the people of Indonesia. Enjoying coffee at a coffee shop has become a way of life for people. The "Kanggo Riko" Coffee Shop, located in Sidoarjo, is a business activity that has a homey concept that has a variety of drink menus. Based on observations, it was found that there were many customer complaints at the "Kanggo Riko" Coffee Shop that affected sales. It is a challenge for the "Kanggo Riko" Coffee Shop to increase customers during intense competition by making various efforts for satisfaction and building customer loyalty. Observing this fact, the "Kanggo Riko" Coffee Shop must be able to increase customer loyalty. From this, it is necessary to have a study that can explain what factors are related and affect customer loyalty at the "Kanggo Riko" Coffee Shop, especially product prices, product diversity, facilities, and locations that affect the level of satisfaction and have a relationship with loyalty. customer. Previous research found the existence of the product, price, location, and promotion together on customer loyalty at the Manado 
fresh mart mall [3]. [4] stated that facilities, services, and location have a significant positive effect on customer loyalty.

Customer loyalty means consumer loyalty to shop at certain retail locations based on several basics to maintain a competitive advantage also helps attract attention and retain loyal consumers [20]. A company must design the right marketing strategy in achieving the company's goal of creating customer loyalty. for example, setting the right price according to market share and economic conditions of the surrounding community can create consumer satisfaction, satisfied consumers can create customer loyalty.

In creating customer loyalty, companies are required to be able to provide quality service and good prices. Argue that price is the amount of money needed to get several combinations of products and services [28]. Price is an important factor for customers in deciding purchases for customers [11].

In addition to price, product diversity is a variation that is owned by a product that shows many options available so that it is easier for consumers to get the desired product so that consumers do not need to spend time and energy looking for the desired product [11].

Facilities are one of the customer's considerations in determining the services to be purchased. Complete facilities will provide the desired comfort and convenience for every customer. Complete facilities affect customer satisfaction and loyalty.

To get loyal consumers, a supportive or strategic location is needed, good service that can make consumers feel satisfied so that later consumers can trust the shopping place which will then form a loyalty from consumers. Strategic location placement provides efficiency and convenience for consumers to make the purchase process [29].

This study was conducted to examine the effect of price, product diversity, facilities, and location on customer loyalty at Kedai Kopi Kanggo Riko Sidoarjo.

\section{Research Methods}

This study uses quantitative methods. Primary data is obtained directly from respondents through questions/questionnaires by respondents. The population in this study were all customers at Kedai Kopi Kanggo Riko Sidoarjo. The size of the sample in this study is based on [7], namely the number of indicators multiplied by 5-10 parameters. So the number of samples used in this study was $20 \times 6=120$ respondents. Measurement of respondents' responses using a 5-point Likert scale, namely: 1 = strongly disagree $-5=$ strongly agree. The sampling technique used the incidental sampling technique. The collected questionnaires were processed using SPSS 22.0 software.

The measuring instrument in this study uses [5], to measure prices with 3 items. Example of an item: The price of the product at the Kanggo Riko Coffee Shop is the main consideration for buying. 4 items are used to measure product diversity from [12]. Examples of items: Products provided by the Kanggo Riko Coffee Shop according to customer wishes. Facilities are measured using 3 items from [6]. Item example: The parking lot at the Kanggoriko coffee shop is spacious. Location using a measuring tool from [25] with 5 items. Item example: I feel that the location of the Kanggo Riko Coffee Shop in Sidoarjo is strategic to visit. Customer loyalty uses 5 items from Maimuna (2020). 
Item example: I feel that the location of the Kanggo Riko Coffee Shop in Sidoarjo is strategic to visit.

\section{Result and Discussion}

Literature review and hypotheses development:

\section{a. Price}

Price is an element of the marketing mix that is flexible which can change at any time based on time and place. Price is the amount of money that must be paid to get products and services. Prices may vary depending on the product or service being sold. Pricing is often a complicated issue for companies because pricing will be a perception for consumers, precisely price perceptions for consumers [27].

There are several price indicators, namely prices according to the ability of consumers to buy, prices according to the products offered, competitive prices when compared to other places [5].

\section{b. Product Diversity}

Product diversity is a variety of products in terms of completeness of products ranging from brands, sizes and quality, and product availability. The variety of products that are varied with quality assurance will create expectations for consumer interest to consume them to meet the life needs of customers [2]. The development of varied products with quality assurance will create expectations for consumer interest to consume them to meet the life needs of consumers.

\section{c. Facility}

Argues that facilities are physical resources that must exist before service is offered to consumers [6]. Facilities can also be anything that makes it easier for consumers to get satisfaction. Because a form of service cannot be seen, cannot be smelled, and cannot be touched, the aspect of physical form becomes important as a measure of service. Consumers who want to find comfort during the process of waiting for the implementation of services will feel more comfortable if the facilities used by customers are made comfortable and attractive. Facilities include cleanliness and comfort of the place, security, and parking [15].

\section{d. Customer loyalty}

Customer loyalty is a deep lasting customer commitment to re-subscribe or repurchase selected products or services consistently in the future [16]. States that customer loyalty includes customers who want to subscribe in the long term, buy repeatedly in the same place, voluntarily recommend products to others, pay more loyalty, namely customer loyalty to return to transactions to use products, and services that have been used by customers. These consumers with greater sacrifice, advocacy loyalty, namely the attitude of customers who provide recommendations to others to repurchase products or services.

\section{e. Price on Customer Loyalty}

Price is one of the important elements for companies to make a profit [24]. The fairness of the price set by the company can affect the customer's intention to buy goods or services. The fairness of the price can affect the perception of being a loyal customer. Customers often want quality products or services at affordable prices and easy to 
obtain. The right price can affect customer satisfaction and encourage repeat purchases of products or services. Customers who have a positive perception will feel satisfied, on the contrary, if the customer has a negative perception then they will not repurchase the product or service. Found that price had a significant effect on customer loyalty. Based on this description, the hypothesis is as follows [18]; [8].

H1 : Price affects Customer Loyalty

Product Diversity on Customer Loyalty: Product diversity is a collection of various products that are sold at affordable prices. The availability of a variety of products will attract more customers to visit the place and make purchases because of the wide variety of products sold [12]. The diversity of products with various kinds, shapes, and sizes can create customer loyalty. The existence of product diversity will affect customer perceptions to decide to repurchase or not. Customer loyalty can be done by providing a variety of products to meet their needs and desires to create customer satisfaction [1]. Research results, states that there is an effect of product with loyalty [3]. Based on this explanation, the hypothesis is formulated as follows:

H2: Product diversity affects customer loyalty

Facilities on Customer Loyalty: One of the factors that influence customer loyalty is the facility. Facilities in the form of physical equipment aim to provide convenience for customers to shop for goods or services [9]. Adequate facilities are needed to provide customer satisfaction directly to meet various needs [23]. More facilities provided to customers will be able to provide satisfaction and ultimately build customer loyalty. This is following the findings of [4], which states that facilities affect loyalty.

H3: Facilities affect Customer Loyalty

Location on Customer Loyalty: The selection of the location to be used must receive special attention by the company because it is wrong to choose the location and type of distribution used, customer satisfaction will be difficult to achieve so that customers will not be loyal. Location determines the success of service because it is closely related to the potential market [13]. Furthermore, the place strategy ensures that customers receive their purchases in the right quantities at the right time and the right place. Establish an effective location strategy that is easily accessible so that consumers feel satisfied and loyal to the company [11].

The results of research, found that location has a significant effect on customer loyalty [30]. Based on the empirical results above, the hypothesis is as follows:

H4: Location affects Customer Loyalty

Price, Product Diversity, Facilities, and Location on Customer Loyalty: Customer loyalty is an important element for a company to create business continuity. Customer loyalty is a form of customer commitment that is reflected in a positive attitude in repeat purchases [23]. Several studies have found such as [18], that the quality of service, product, price, and location affect customer loyalty. [4] found that facility, service, and location variables had a significant positive effect on customer loyalty. Based on these empirical findings, the following hypotheses were formulated:

H5: Price, Product Diversity, Facilities, and Location to Customer Loyalty 
Result and Discussion: An instrument is declared valid if $r$ count $>r$ table, if the value of $r$ count $r$ table then the result is declared invalid. The research instrument can be said to be reliable if the Cronbach's alpha value is $>0.6$.

Table 1 Validity and Reliability Results

\begin{tabular}{clllll}
\hline Variable & Description & Rbobot & Rtable & $\begin{array}{l}\text { Cronbach's } \\
\text { Alpha }\end{array}$ & Criteria \\
\hline Price(X1) & X1.1 & 0.850 & 0.179 & 0.923 & 0.6 \\
& X1.2 & 0.867 & 0.179 & & \\
& X1.3 & 0.856 & 0.179 & & \\
Product & X2.1 & 0.744 & 0.179 & 0.904 & 0.6 \\
Diversity & X2.2 & 0.774 & 0.179 & & \\
(X2) & X2.3 & 0.837 & 0.179 & & \\
& X2.4 & 0.775 & 0.179 & & \\
Facility & X3.1 & 0.877 & 0.179 & 0.894 & 0.6 \\
(X3) & X3.2 & 0.857 & 0.179 & & \\
& X3.3 & 0.897 & 0.179 & & \\
Location & X4.1 & 0.695 & 0.179 & 0.920 & 0.6 \\
(X4) & X4.2 & 0.796 & 0.179 & & \\
& X4.3 & 0.830 & 0.179 & & \\
& X4.4 & 0.801 & 0.179 & & \\
Customer & Y4.5 & 0.732 & 0.179 & & \\
Loyalty & Y2 & 0.511 & 0.179 & 0.906 & 0.6 \\
(Y) & Y3 & 0.746 & 0.179 & & \\
& Y4 & 0.749 & 0.179 & & \\
& Y5 & 0.841 & 0.179 & & \\
\hline & (Source : SPSS Output (Processed Data)) & \\
& & & & \\
& & &
\end{tabular}

Table 1 shows that all items from all variables are known to get an rcount value of more than rtable (rcount > rtable), so it can be concluded that the research instrument used is valid. In the price variable, product diversity, facilities, location and customer loyalty, Cronbach's alpha value is greater than 0.6. It can be concluded that the research instrument is reliable.

Hypothesis test

\section{Partial Test (t-Test)}

The t-test is used to show how much influence one independent variable has individually in explaining the variation in the dependent variable. In testing the validity of the expected sig value is less than 0.05 then the hypothesis is accepted. On the other hand, the sig value is greater than 0.05 , so the hypothesis is rejected.

Table 2 Hypothesis t Test Results

\begin{tabular}{llll}
\hline Variable & $\mathbf{t}$ & Sig. & criteria \\
\hline Price $\left(\mathrm{X}_{1}\right)$ & 3,354 & 0,001 & Significant \\
Product Diversity $\left(\mathrm{X}_{2}\right)$ & 2,384 & 0,019 & Significant \\
Facility $\left(\mathrm{X}_{3}\right)$ & 2,205 & 0,029 & Significant \\
Location $\left(\mathrm{X}_{4}\right)$ & 3,298 & 0,001 & Significant \\
\hline
\end{tabular}




\begin{tabular}{|c|c|c|c|}
\hline Variable & $\mathbf{t}$ & Sig. & criteria \\
\hline Depend & & & \\
\hline
\end{tabular}

(Source: Processed Data)

\section{Simultaneous Test (F Test)}

The F test was conducted to test the suitability of the multiple regression model that has been carried out to test the significance of the simultaneous effect between price (X1), product diversity (X2), facilities (X3), and location (X4) on customer loyalty (Y). If the expected sig value is less than 0.05 then the hypothesis is accepted. On the other hand, the sig value is greater than 0.05 , so the hypothesis is rejected.

Table 3 F Test Result

\begin{tabular}{cccc}
\hline Model & F & Sig. & Criteria \\
\hline 1 & 44.306 & 0.000 & Significant \\
\hline Dependent variable: Customer Loyalty & & \\
\hline
\end{tabular}

(Source: SPSS Processed Data)

Table 2 it can be explained the results of the $\mathrm{H} 1$ test with a sig value. less than $0.05(0.001<0.05)$ this indicates that the price has a significant effect on customer loyalty. These results indicate that $\mathrm{H} 1$ is accepted, meaning that there is a positive and significant effect of price on customer loyalty. This result reflects that the better the price offered by the Kanggo Riko Coffee Shop, Sidoarjo, the higher customer loyalty. Appropriate pricing to create customer loyalty. The price set by the Kanggo Riko Sidoarjo Coffee Shop is by the capabilities and needs of the customer. It is proven by the answers of respondents who buy products at the Kanggo Riko Coffee Shop Sidoarjo twice a week. The results of this study are in line with the research of Sugiarsih Duki Saputri (2019) which proves that price affects customer loyalty. This proves that the right price given by the company will increase customer loyalty to the company. A good price is balanced with good product quality, so customers will be more loyal to the company.

Furthermore, the results of $\mathrm{H} 2$ show the value of sig. less than $0.05(0.019<0.05)$ this means that product diversity has a significant effect on customer loyalty. It can be said that the second hypothesis $(\mathrm{H} 2)$ proposed is accepted. These results explain that the more varied the products offered, the higher customer loyalty at the Kanggo Riko Coffee Shop Sidoarjo. The variety of products created by the Kanggo Riko Coffee shop is in accordance with the needs or desires of customers so that they are able to attract the attention of customers to make repeat purchases. The results of this study strengthen the findings of Rohmawati (2018) that the variety of available products can attract consumers and make consumers loyal to the "Kanggo Riko" Coffee Shop.

While the results of $\mathrm{H} 3$ that facilities affect customer loyalty at the Kanggo Riko Coffee Shop Sidoarjo are shown by the value of sig. less than $0.05(0.029<0.05)$. It means that it can be concluded that the third hypothesis (H3) is accepted, meaning that the better the facilities provided, the higher the customer loyalty at Kedai Kopi Kanggo Riko Sidoarjo. The facilities provided at the Kanggo Riko Coffee Shop Sidoarjo are a clean and comfortable place, good security, and a large parking space. Facilities are one of the important elements to support comfort for customers. Facilities are one of the customer's 
considerations in determining the services to be purchased. Adequate facilities will provide comfort for every customer. The results of this study are supported by [14], that facilities have a positive and significant effect on customer loyalty at Cafe Zybrick Coffee \& Cantina.

Furthermore, the results of $\mathrm{H} 4$ are known to have sig values. less than 0.05 (0.001 $<0.05)$. This shows that location has a significant effect on customer loyalty, meaning H4 is accepted. It can be said that the more strategic the location of the Kanggo Riko Sidoarjo Coffee Shop, the more customer loyalty will be. The location determination carried out by the Kanggo Riko Sidoarjo Coffee Shop is a determining element of customer satisfaction, an easy-to-access location results in high consumer satisfaction, strategic location selection provides efficiency and convenience for consumers to make the purchase process [29]. The results of this study are supported by previous research from [30] that a strategic location can affect customer loyalty.

Based on Table 3, it is known that the value of sig. less than $0.05(0.000<0.05)$, it can be concluded that the fifth hypothesis (H5) is accepted. This means that with a good price, product diversity, facilities, and location, customer loyalty at Kedai Kopi Kanggo Riko Sidoarjo is getting better. The better customer loyalty, the more customers will want to subscribe in the long term, buy repeatedly in the same place, voluntarily recommend products to others to repurchase products or services.

Table 4 F Test Result

\begin{tabular}{ccccc}
\hline Model & R & R Square & $\begin{array}{c}\text { Adjusted R } \\
\text { Square }\end{array}$ & $\begin{array}{c}\text { Std. Error of the } \\
\text { Estimate }\end{array}$ \\
\hline 1 &, 676 &, 457 &, 439 & 4,30200 \\
\hline
\end{tabular}

a. Predictors: (Constant), Price, Product Diversity, Facilities, and Location

b. Dependent Variable: Customer Loyalty (Source: SPSS Processed Data)

Based on the results in Table 4, it is known that the coefficient of determination is 0.457 , meaning that the variables of price, product diversity, facilities, and location influence customer loyalty at the Kanggo Riko Coffee Shop Sidoarjo by $45.10 \%$. As for $54.90 \%$ influenced by other variables not contained in this study.

\section{Conclusion}

Based on the results of research and discussion, it can be concluded that based on the results of the t-test on multiple regression, it shows that each variable price, product diversity, facilities, and location have a significant effect on customer loyalty at Kedai Kopi Kanggo Riko Sidoarjo. This means that hypotheses 1, 2, 3, and 4 are accepted. Furthermore, the results of the $\mathrm{F}$ test prove that simultaneously price, product diversity, facilities, and location have a significant effect on customer loyalty at Kedai Kopi Kanggo Riko Sidoarjo. This means that hypothesis 5 is accepted.

This study has a limited number of samples that are only found in the Sidoarjo area so it cannot generalize to other areas. For future research, it is better to add a mediating variable of customer satisfaction. This is intended to create loyalty, the customer must feel satisfaction first. 


\section{References}

[1] Alfin Rita, T. A., Nimran, U. \& Suharyono. (2013). Effect of Service Quality and Product Quality to Corporate Costumer's Satisfaction and Customer's Trust. IOSR Journal of Business and Management, 9 (6), 1-9.

[2] Aminudhin, I. (2020). Loyalitas Konsumen Ditinjau Dari Kepercayaan, Komunikasi Dan Keragaman Produk (Studi Kasus Di Pasar Klewer). Prosiding Seminar Nasional, 1(01), 42-47.

[3] Anggia, T. R., Kawet, L., \& Ogi, I. (2015). Analisis pengaruh strategi promosi, harga, dan kepuasan terhadap loyalitas konsumen surat kabar manado post. Jurnal EMBA: Jurnal Riset Ekonomi, Manajemen, Bisnis Dan Akuntansi, 3(2), 10411050.

[4] Annas, A. N., Arifin, R., \& Hufron, M. (2019). Pengaruh Fasilitas Dan Lokasi Terhadap Loyalitas Pelanggan Melalui Kepuasan Sebagai Variabel Intervening (Studi Kasus Konsumen Awi Futsal Laok Jang-Jang, Sumenep). Jurnal Ilmiah Riset Manajemen, 8(05), 43-61.

[5] Ariningtyas, E. (2020). Menguji Pengaruh Keragaman Menu, Kualitas Produk, Store Atmosphere, Dan Harga Terhadap Loyalitas Pelanggan Di Wedangan Jimboeng. EXCELLENT, 7(1), 115-123.

[6] Audistiana, A. (2017). Pengaruh Aksesibilitas, Fasilitas dan Kepuasan Pelanggan Terhadap Loyalitas Pelanggan di Delta Fishing Sidoarjo. E-Journal Manajemen" BRANCHMARCK", 3(3), 26- 38.

[7] Ferdinand, Augusty. (2014). Metode Penelitian Manajemen. BP Universitas Diponegoro. Semarang.

[8] Halimah, M. A., \& Yanti, R. D. (2020). Pengaruh Strategi Penetapan Harga TerhadapLoyalitas Pelanggan Produk Kilat Khusus Mitra Korporat Kantor Pos Purwokerto. Jurnal Ecoment Global: Kajian Bisnis Dan Manajemen, 5(1), 70-79.

[9] Haliza, L. N., Purwanti, I., Wicaksono, A. Y., \& Lailyningsih, D. R. N. (2020). Kualitas Pelayanan Dan Fasilitas Terhadap Kepuasan Pasien (Studi pada Ruang Rawat Inap RSI Nashrul Ummah Lamongan). Jurnal Media Komunikasi Ilmu Ekonomi STIEKHAD, 36 (3), 131-141.

[9] Józsa, T. (2017). The antecedents of market orientation and its effect on customer satisfaction and service quality: The case of Hungarian municipal public service provisions. International Review on Public and Nonprofit Marketing, 14(3), 391407.

[10] Kim, S.-H., \& Yoo, B.-K. (2015). Analysis of the Factors Affecting Customer Satisfaction and Customer Loyalty in a Family Restaurant Chain. Journal of Distribution Science, 13(5), 103-111.

[11] Kotler, Philip \& Amstrong, Gary. (2012). Principles of Marketing, 15th Edition, Pearson Education Limited.

[12] Kotler, P. \& Keller, K.L. (2012). Manajemen Pemasaran, Jilid I Edisi ke 12. Jakarta: Erlangga.

[13] Lupiyodi, Rambat. (2013). Manajemen Pemasaran. Edisi 3. Jakarta: Salemba Empat. 
[14] Michelle \& Siagian, H. (2019). Pengaruh Kualitas Layanan Dan Fasilitas Terhadap Loyalitas Pelanggan Melalui Kepuasan Pelanggan Cafe Zybrick Coffee \& Cantina, AGORA, 7(1), 1-6.

[15] Mongkaren, S. (2013). Fasilitas Dan Kualitas Pelayanan Pengaruhnya Terhadap Kepuasan Penguna Jasa Rumah Sakit Advent Manado. Jurnal Riset Ekonomi, Manajemen, Bisnis Dan Akuntansi, 1(4), 493-503.

[16] Nastiti, A., \& Astuti, S. R. T. (2019). Pengaruh Persepsi Harga, Kualitas Layanan Dan Citra Merek Terhadap Kepuasan Pelanggan dan Dampaknya Terhadap Loyalitas Pelanggan Taksi New Atlas di Kota Semarang. Diponegoro Journal of Management, 126-136.

[17] Prasetio, A. (2012). Pengaruh Kualitas Pelayanan dan Harga Terhadap Kepuasan Pelanggan.Management Analysis Journal, 1(1), 1-6.

[18] Rahmadani, F., Suardana, I. M., \& Samudra, H. (2019). Pengaruh Kualitas Pelayanan, Produk, Harga Dan Lokasi Terhadap Loyalitas Pelanggan Dengan Kepuasan Pelanggan Sebagai Variabel Intervening Pada Ud. Eva Group Mataram. VALID Jurnal Ilmiah, 16(1), 123-135.

[19] Ramlawati, R., \& Putra, A. H. P. K. (2018). Total Quality Management as the Key of the Company to Gain the Competitiveness, Performance Achievement and Consumer Satisfaction. International Review of Management and Marketing, 8(5), 60-69.

[20] Rohmawati, Z. (2018). Kualitas, Harga dan Keragaman Produk Terhadap Loyalitas Pelanggan.Jurnal Riset Entrepreneurship, 1(2), 19-29.

[21] Sugiarsih Duki Saputri, R. (2019). Pengaruh Kualitas Pelayanan dan Harga Terhadap Loyalitas Pelanggan Grab Semarang. CoverAge: Journal of Strategic Communication, 10(1), 46-53.

[22] Sulastiyono, A. (2011). Manajemen Penyelenggaraan Hotel. Seri Manajemen Usaha Jasa Sarana Pariwisata dan Akomodasi. Alfabeta. Bandung.

[23] Tjiptono, Fandy. (2016). Service, Quality \& satisfaction. Yogyakarta. Andi

[24] Virvilaite, R., Saladiena, V., Skindaras, D. (2009). The Relationship Between Price and Loyalty in Services Industry. Journal Inzinerine Ekonomika Engineering Economics, 3, 96-104.

[25] Wasiman, Slitonga, F., \& Wibowo, A. E. (2020). Pengaruh Kualitas Pelayanan Dan Lokasi Terhadap Loyalitas Pelanggan Hotel Bintang Dua Di Kota Batam. Jurnal Cafetaria, 1(2), 64-73.

[27] Wibowo, S. F., \& Karimah, M. P. (2012). Pengaruh Iklan Televisi Dan Harga Terhadap Keputusan Pembelian Sabun Lux (Survei Pada Pengunjung Mega Bekasi Hypermall). JRMSI-Jurnal Riset Manajemen Sains Indonesia, 3(1), 1-15.

[28] Winata, A., \& Fiqri, I. A. (2017). Pengaruh Harga Dan Kualitas Jasa Terhadap Loyalitas Pelanggan Hotel Emersia Di Bandar Lampung. Jurnal Manajemen Magister Darmajaya, 3(02), 133-149.

[29] Wirawan, A. A., Sjahruddin, H., \& Razak, N. (2019). Pengaruh Kualitas Produk dan Lokasi Terhadap Loyalitas Pelanggan Melalui Kepuasan Pelanggan Sebagai Variabel Intervening Pada Lamuna Coffee di Kabupaten Bone. Jurnal Organisasi Dan Manajemen, 1, 15-24. 
[30] Zardi, H., Wardi, Y., \& Evanita, S. (2018). Effect of Quality Products, Prices, Locations and Customer Satisfaction to Customer Loyalty Simpang Raya Restaurant Bukittinggi "Salero Nan Tau Raso", Advances in Economics, Business and Management Research, 64, 856-865.ation 